Original research article

\title{
Toxicity assessment of Hypericum olympicum subsp. olympicum L. on human lymphocytes and breast cancer cell lines
}

\author{
Necmiye Balikci ${ }^{1}$, Mehmet Sarimahmut ${ }^{1}$, Ferda Ari ${ }^{1}$, Nazlihan Aztopal ${ }^{1,2}$, Mustafa Zafer Özel ${ }^{3}$, \\ Engin Ulukaya ${ }^{1,4}$, Serap Celikler ${ }^{1 *}$ \\ ${ }^{1}$ Uludag University, Faculty of Science and Arts, Department of Biology, Bursa, Turkey \\ ${ }^{2}$ Istinye University, Faculty of Science and Literature, Department of Molecular Biology and Genetics, Istanbul, Turkey \\ ${ }^{3}$ University of York, Department of Chemistry, Heslington, York, United Kingdom \\ ${ }^{4}$ Istinye University, Faculty of Medicine, Department of Medical Biochemistry, Istanbul, Turkey
}

\section{Abstract}

There is a limited number of studies about the constituents of Hypericum olympicum subsp. olympicum and its genotoxic and cytotoxic potency. We examined the possible antigenotoxic/genotoxic properties of methanolic extract of H. olympicum subsp. olympicum (HOE) on human lymphocytes by employing sister chromatid exchange, micronucleus and comet assay and analyzed its chemical composition by GCxGC-TOF/MS. The anti-growth activity against MCF-7 and MDA-MB-231 cell lines was assessed by using the ATP viability assay. Cell death mode was investigated with fluorescence staining and ELISA assays. The major components of the flower and trunk were determined as eicosane, heptacosane, 2-propen-1-ol, hexahydrofarnesyl acetone and $\alpha$-muurolene. HOE caused significant DNA damage at selected doses $(250-750 \mu \mathrm{g} / \mathrm{ml}$ ) while chromosomal damage was observed at higher concentrations (500 and $750 \mu \mathrm{g} / \mathrm{ml}$ ). HOE demonstrated anti-growth activity in a dose-dependent manner between 3.13-100 $\mu \mathrm{g} / \mathrm{ml}$. Pyknotic nuclei were observed at $100 \mu \mathrm{g} / \mathrm{ml}$ concentration of HOE in both cell lines. In conclusion, HOE demonstrated cytotoxic effects in a cell type-dependent manner, however its genotoxic effects were observed at relatively higher doses.
\end{abstract}

Keywords: Breast cancer; Cytotoxicity; Folk medicine; Genotoxicity; Human lymphocyte; Hypericum olympicum

\section{Highlights:}

- Genotoxic and cytotoxic properties of Hypericum olympicum were investigated.

- Volatile compounds in methanol extract of Hypericum olympicum plant were revealed.

- Strong anti-growth activity was observed in a cell type dependent manner.

- Genotoxicity was observed at much higher concentrations than the doses required for cytotoxicity.

\section{Introduction}

Medicinal plants are considered as an ample source of ingredients which can be utilized in drug development and synthesis especially in cancer treatment. Eighty-three percent of the clinically approved small molecule anticancer drugs from the year 1981 to 2014 are classified as either a natural product or based thereon in one way or another (Newman and Cragg, 2016). A significant portion of these drugs are particularly associated with plants. Plant-derived traditional medicines along with plant extracts are sustaining the primary healthcare needs of a significant portion of the population in the developing countries (WHO, 1999). Appropriate usage of medicinal plant extracts requires the identification of the exact chemical composition, determination of effective and toxic concentra- tions (Briskin, 2000). In addition, genotoxicity studies may be invaluable where the medicinal plants bearing potential health risks have not been thoroughly elucidated (Bast et al., 2002).

Volatile substances found in plants are commonly investigated through an extraction step, a subsequent concentration, chromatographic analysis and detection steps. Direct thermal desorption (DTD) is a type of dynamic headspace technique coupled with GC-MS that enables rapid analysis and reduces required sample amount. DTD is therefore a more convenient method for prompt qualitative and quantitative analysis of compounds (Özel et al., 2006).

Hypericum genus is represented worldwide with over 400 species (Davis et al., 1988; Guner et al., 2000). Around eightyfour species of the genus are found throughout Turkey especially in Marmara region (Davis et al., 1988; Guner et al., 2000). Numerous species from Hypericum genus are being uti-

\footnotetext{
* Author for correspondence: Serap Celikler, Uludag University, Faculty of Science and Arts, Department of Biology, 16059 Bursa, Turkey; e-mail: scelikler@uludag.edu.tr http://doi.org/10.32725/jab.2020.002

Submitted: 2019-07-12 • Accepted: 2020-01-23 • Prepublished online: 2020-02-20

J Appl Biomed 18/1: 18-25 • EISSN 1214-0287 • ISSN 1214-021X

(c) 2020 The Authors. Published by University of South Bohemia in České Budějovice, Faculty of Health and Social Sciences.

This is an open access article under the CC BY-NC-ND license.
} 
lized as herbal remedies around the world and are investigated for medicinal applications. It has been shown that either whole extract or some biologically active constituents of different Hypericum species exhibit anti-inflammatory, anti-microbial, anti-depressant, anti-oxidant and anti-tumor activity (Bender et al., 2018; Ozkan et al., 2018; Tian et al., 2014; Zorzetto et al., 2015). Furthermore, cytotoxic, genotoxic and apoptosis-inducing effects against different cancer cells have also been highlighted in recent studies (Keskin et al., 2017; Mirmalek et al., 2015; Sarimahmut et al., 2016; Sousa et al., 2015). The most renowned Hypericum species, Hypericum perforatum (St. John's Wort), is extensively studied and utilized in traditional medicine due to its antidepressant activity and in burn-wound-healing with many pharmacological properties due to its active ingredients hypericin, hyperforin and other flavonoid compounds (Barnes et al., 2001; Baytop, 1984).

H. olympicum subsp. olympicum, a dwarf deciduous shrub, is native to Western Asia (Syria and Turkey) and Southeastern Europe (Albania, Bulgaria, Greece, Macedonia, Montenegro, Serbia) (Davis et al., 1988). Decoction from the aerial parts of H. olympicum subsp. olympicum is utilized in folk medicine for inflamed wounds, stomach ache, and cuts (Bingol et al., 2011; Tuzlacı and Aymaz, 2001). Available research on H. olympicum subsp. olympicum species shows that the crude ethanol extract of the plant exhibits a prominent antioxidant effect and inhibits acetylcholinesterase activity (Božin et al., 2013). Also, a growth inhibitory and programmed cell death inducing effects of $H$. olympicum subsp. olympicum extract in lung cancer cells was previously reported by our research group (Aztopal et al., 2016).

We examined the genotoxic and cytotoxic activities of H. olympicum subsp. olympicum extract (HOE) in human lymphocytes and breast cancer cell lines, respectively. The volatile components of the extract were detected by using the GCxGCTOF/MS.

\section{Materials and methods}

\section{Extraction and chromatographic analysis of H. olympicum subsp. olympicum}

H. olympicum subsp. olympicum was collected from Mt. Uludag region in Bursa, Turkey. A methanolic extract from $30 \mathrm{~g}$ of the trunk and flowers of this plant was prepared by utilizing a Soxhlet apparatus as previously described (Aztopal et al., 2016). The sample was lyophilized and kept at $-20^{\circ} \mathrm{C}$ for further use.

\section{Chromatographic analysis of $\mathrm{HOE}$}

The content of the trunk and flower parts of $H$. olympicum subsp. olympicum was determined by GCxGC-TOF/MS method. The GCxGC-TOF/MS system consisted of an Agilent 6890 (Agilent Technologies, Palo Alto, CA, USA) gas chromatograph and a Pegasus III TOF-MS (LECO, St. Joseph, MI, USA). The chromatographic separation was made as described by Ari et al. (2015).

\section{Lymphocyte cultures and cell harvesting}

A total of four blood samples from non-smoker healthy donors between the ages of 18 and 25 were collected into EDTA tubes and used throughout the experiment. The lymphocytes were treated with $0.1 \%$ dimethyl sulfoxide (DMSO) as solvent control, $1.250 \mathrm{mg} / \mathrm{ml}$ ethyl methane sulfonate (EMS) as positive control, $250-750 \mu \mathrm{g} / \mathrm{ml}$ diluted sterile extract of $H$. olympicum subsp. olympicum and with lymphocyte culture medium as negative control. HOE concentrations were deter- mined following the preliminary tests carried out with 10,50 , $100,250,500,750,1000,1250,1500$ and $1750 \mu \mathrm{g} / \mathrm{ml}$ concentrations prepared from lyophilized powder $(\geq 1000 \mu \mathrm{g} /$ $\mathrm{ml}$ dose was highly toxic; data not shown). A dose range of $250-750 \mu \mathrm{g} / \mathrm{ml}$ was selected for further experiments. Stock HOE solution was diluted and sterile filtered with a 0.22 micron syringe filter before use in further experiments. Micronucleus (MN) assay was performed using the method described by Fenech with minor modifications as depicted in our previous work (Ari et al., 2015; Fenech, 2000). For sister chromatid exchange (SCE) analyses, lymphocyte cells were cultivated for 72 hours at dark in the presence of $10 \mu \mathrm{g} / \mathrm{ml} \mathrm{5-bromodeox-}$ yuridine (BrdUrd; Sigma) to detect cell proliferation via incorporating BrdUrd into the DNA after the first and second or more cell cycles. Addition of colcemid (Sigma; at $0.2 \mu \mathrm{g} / \mathrm{ml}$ final concentration) two hours before the completion of the treatment was followed by lymphocyte harvest. The slides with well spread chromosomes were stained according to the fluorescence plus Giemsa method (Perry and Wolff, 1974).

Comet assay was performed to assess DNA damage as detailed by Singh et al. (1988) with minor modifications. Electrophoresis conditions were set as previously described (Sarimahmut et al., 2016).

\section{Microscopic evaluation}

Microscopic evaluations for MN and comet assay were employed as previously described (Barnes et al., 2001). Sister chromatid exchange was scored according to the study of Carrano and Natarajan (1988). The frequency of SCE per cell was recorded in each group from a total of 50 well-spread, complete second division metaphases.

Proliferative index (PRI) was consecutively calculated by analyzing 200 cells in each group using the formula: $\mathrm{PRI}=\left(\mathrm{M}_{1}\right.$ $\left.+2 M_{2}+3 M_{3}\right) / N$. Here, $M_{1}, M_{2}$ and $M_{3}$ depict the number of metaphases at the first, second and third cell division, respectively and $\mathrm{N}$ depicts the total number of scored metaphases (Lamberti et al., 1983).

Nuclear division index (NDI) was calculated among the 500 lymphocytes that were scored in MN assay according to the following equation: $\mathrm{NDI}=(\mathrm{MONO}+2 \mathrm{BN}+3 \mathrm{TRI}+4 \mathrm{TET}-$ RA)/500. Here, MONO, BN, TRI and TETRA depicts the number of mononucleated, binucleated, trinucleated and tetranucleated lymphocytes, respectively.

\section{Cell culture}

MCF-7 and MDA-MB-231 breast cancer cell lines were incubated at $37{ }^{\circ} \mathrm{C}$ in RPMI 1640 medium. The medium was supplemented with 1\% Pen/Strep solution (Invitrogen) and 5\% fetal calf serum (Invitrogen). A stock solution at $100 \mathrm{mg} / \mathrm{ml}$ concentration was prepared from lyophilized HOE by dissolving it in DMSO. Obtained stock solution was further diluted in culture medium and sterilized by a 0.22 micron filter. The cells were treated with different concentrations of HOE ranging from 3.13 to $100 \mu \mathrm{g} / \mathrm{ml}$.

\section{Determination of anti-growth activity}

The human MCF-7 or MDA-MB-231 breast cancer cell lines were seeded in 96-well plate containing $5 \times 10^{3}$ cells per well with $200 \mu \mathrm{l}$ medium. Cells were incubated $72 \mathrm{~h}$ either with $0.1 \%$ DMSO for negative control or with different concentrations $(3.13-100 \mu \mathrm{g} / \mathrm{ml})$ of HOE. Two independent experiments run in triplicates were carried out for ATP viability assay as previously described (Ulukaya et al., 2008). ATP content was determined as per manufacturer's instructions (Sigma; product code FLASC). Shortly, the cells were lysed to extract 
ATP, a luciferin-luciferase solution was added and the resulting luminescence was measured in a luminometer (Bio-Tek, USA). Untreated cells were used as a reference to calculate the viability of treated cells. The concentration that inhibits $50 \%$ of the cell viability $\left(\mathrm{IC}_{50}\right)$ was determined from the concentration versus $\%$ viability graph.

\section{Determination of cell death mode}

Fluorescence imaging for detection of cell death mode

MCF-7 and MDA-MB-231 cells were seeded at the density of $1 \times 10^{4}$ cells per well in 96-well plates and treated with HOE $(100 \mu \mathrm{g} / \mathrm{ml})$ for $72 \mathrm{~h}$. The type of cell death was evaluated based upon the integrity of the cell membrane and the nuclear morphology. Hoechst 33342, propidium iodide (PI) and calcein-AM (Roche, Germany) were added into the wells subsequent to treatment and the cells were analyzed via fluorescent microscope (Olympus CKX41, Japan).

Assessing caspase-cleaved cytokeratin 18 (M30), active caspase-3 and cleaved PARP levels

The induction of apoptosis was investigated through measuring the levels of caspase-cleaved keratin 18 (M30), active caspase-3 and cleaved PARP. MCF-7 cells at the density of $1 \times 10^{4}$ cells per well were seeded in 96-well plate for M30 assay and $1 \times 10^{6}$ MCF-7 and MDA-MB-231 at the density of $1 \times 10^{6}$ cells were seeded in T25 flasks to determine the levels of active caspase- 3 and cleaved PARP. The cells were incubated $72 \mathrm{~h}$ with $25-100 \mu \mathrm{g} / \mathrm{ml}$ of HOE in M30 assay and $100 \mu \mathrm{g} / \mathrm{ml}$ of HOE was selected in order to analyze active caspase- 3 and PARP levels. Each experiment was performed twice. Paclitaxel $(3.12 \mu \mathrm{M})$ was employed as positive control against the breast cancer cell lines in all experiments. M30 assay was not performed in MDA-MB-231 cells because of low cytokeratin 18 expression levels found in this cell line (Sommers et al., 1992). The ELISA assays were implemented as described previously (Kasımoğulları et al., 2014).

\section{Statistical analyses}

All statistical analyses were carried out using the SPSS 23.0 program (SPSS Inc., Chicago, IL, USA). To assess significance, one-way analysis of variance (ANOVA) and Tukey Honest Significant Difference (HSD) were conducted after performing a normality test. A $p$ value less than 0.05 was considered statistically significant.

\section{Results}

\section{Chemical analyses of $\mathrm{HOE}$}

DTD of volatiles obtained from flower and trunk of H. olympicum subsp. olympicum were listed in Table 1 . Identification is based on a mass spectral library search using similarity and reverse factors above 750 and 800, respectively (Özel et al., 2004). The total detected number of volatiles for the flower and trunk were 106 and 100, respectively. The major components of the flower and trunk were determined as eicosane, heptacosane, 2-propen-1-ol, hexahydrofarnesyl acetone and a-muurolene.
Table 1. The results of chromatographic analysis of Hypericum olympicum subsp. olympicum

\begin{tabular}{|c|c|c|c|}
\hline \multirow[b]{2}{*}{ Compound $^{\mathrm{a}}$} & \multirow[b]{2}{*}{$\mathrm{RI}^{\mathrm{b}}$} & \multicolumn{2}{|c|}{$\%$ Area $^{c}$} \\
\hline & & Flower & Trunk \\
\hline Acetic acid & 600 & 2.68 & 0.08 \\
\hline 2-Propanone, 1-hydroxy- & 672 & d & 1.15 \\
\hline Pyrrole & 749 & 0.04 & \\
\hline Butanoic acid & 763 & 0.22 & 0.33 \\
\hline Propanoic acid, 2-methyl- & 763 & & 0.96 \\
\hline 2,3-Butanediol & 785 & 0.20 & \\
\hline Hexanal & 801 & & 0.52 \\
\hline Methyl pyrazine & 819 & & 0.07 \\
\hline Furfural & 828 & 0.55 & 2.01 \\
\hline Butanoic acid, 2-methyl- & 832 & 0.51 & 0.27 \\
\hline 2-Furanmethanol & 866 & 0.50 & 1.22 \\
\hline 2(5H)-Furanone & 871 & 0.46 & 0.73 \\
\hline Heptanal & 901 & & 0.77 \\
\hline Pyrazine, ethyl- & 907 & 0.10 & \\
\hline Pyrazine, 2,5-dimethyl- & 908 & 0.46 & 0.11 \\
\hline Pentanoic acid & 911 & 0.43 & 0.85 \\
\hline Pyrazine, 2,3-dimethyl- & 915 & 0.10 & \\
\hline$\alpha$-Pinene & 939 & 0.17 & \\
\hline 2-Furancarboxaldehyde, 5-methyl- & 942 & 0.37 & 0.29 \\
\hline 2(5H)-Furanone, 5,5-dimethyl- & 951 & 0.86 & 0.11 \\
\hline Benzaldehyde & 952 & 0.08 & 0.26 \\
\hline Hexanoic acid & 967 & 2.74 & 0.91 \\
\hline Phenol & 980 & 0.24 & 0.21 \\
\hline$\beta$-Pinene & 981 & 0.09 & \\
\hline 2(5H)-Furanone, 3-methyl- & 983 & 0.08 & 0.22 \\
\hline 5-Hepten-2-one, 6-methyl- & 985 & 0.75 & 0.36 \\
\hline$\beta$-Myrcene & 988 & 0.36 & \\
\hline 2-Octanone & 988 & 0.41 & 0.76 \\
\hline Furan, 2-pentyl- & 992 & & 0.72 \\
\hline Octanal & 998 & & 0.76 \\
\hline Pyrazine, 2-ethyl-3-methyl- & 1001 & 0.19 & \\
\hline 2,4-Heptadienal & 1005 & 0.07 & 0.38 \\
\hline o-Cymene & 1020 & & 0.07 \\
\hline Benzyl Alcohol & 1026 & 0.29 & 0.23 \\
\hline Hexanoic acid, 2-ethyl- & 1027 & 0.15 & 0.21 \\
\hline 1-Hexanol, 2-ethyl- & 1032 & & 0.14 \\
\hline 2-Acetylpyridine & 1035 & 0.50 & 0.12 \\
\hline Benzeneacetaldehyde & 1036 & 0.58 & 0.61 \\
\hline Butyl 3-methylbutanoate & 1047 & 0.38 & 0.20 \\
\hline Acetophenone & 1059 & 0.12 & 0.12 \\
\hline 2-Nonyne & 1068 & & 0.26 \\
\hline Pyrazine, 3-ethyl-2,5-dimethyl- & 1082 & 0.08 & 0.06 \\
\hline Heptanoic acid & 1083 & 1.05 & 1.89 \\
\hline 2-Nonanone & 1087 & 0.13 & 0.22 \\
\hline Nonanal & 1100 & 0.41 & 1.28 \\
\hline
\end{tabular}


Table 1 (Continued)

\begin{tabular}{|c|c|c|c|}
\hline \multirow[b]{2}{*}{ Compound $^{\mathrm{a}}$} & \multirow[b]{2}{*}{$\mathrm{RI}^{\mathrm{b}}$} & \multicolumn{2}{|c|}{$\%$ Area $^{c}$} \\
\hline & & Flower & Trunk \\
\hline Undecane & 1100 & 0.12 & 1.47 \\
\hline Phenylethyl Alcohol & 1106 & 0.10 & 0.04 \\
\hline Maltol & 1106 & 0.07 & 0.14 \\
\hline 2(3H)-Furanone, dihydro-5-propyl- & 1130 & 0.21 & 0.29 \\
\hline $\begin{array}{l}\text { 2(3H)-Furanone, ethyl-4- } \\
\text { hydroxymethyl- }\end{array}$ & 1139 & 0.20 & 0.27 \\
\hline Furaneol & 1139 & 0.54 & 0.31 \\
\hline Camphor & 1143 & 0.11 & 0.16 \\
\hline 2,6-Nonadienal & 1150 & & 0.12 \\
\hline 2-Nonenal & 1157 & & 0.23 \\
\hline Borneol & 1165 & 0.08 & \\
\hline Octanoic Acid & 1167 & 1.54 & 2.98 \\
\hline Melilotal & 1181 & 0.11 & 0.11 \\
\hline 2-Decanone & 1190 & 0.07 & 0.27 \\
\hline 1,2-Benzenediol & 1197 & 0.11 & 0.14 \\
\hline Decanal & 1204 & 0.21 & 0.57 \\
\hline 2-Phenoxyethanol & 1245 & 0.22 & 0.12 \\
\hline Nonanoic acid & 1267 & 1.95 & 3.20 \\
\hline Thymol & 1289 & 0.09 & \\
\hline Indole & 1290 & 0.04 & \\
\hline 2-Undecanone & 1293 & 0.60 & \\
\hline Butyrolactone & 1299 & 0.65 & 1.13 \\
\hline 2-Methoxy-4-vinylphenol & 1313 & 0.23 & 0.09 \\
\hline a-Cubebene & 1345 & 1.01 & 0.16 \\
\hline n-Decanoic acid & 1364 & 0.51 & 0.94 \\
\hline Biphenyl & 1375 & & 0.04 \\
\hline Tetradecane & 1400 & 0.19 & 0.15 \\
\hline Diisobutyl phthalate & 1442 & 1.91 & 1.15 \\
\hline 2-Propen-1-ol & 1448 & 2.81 & 3.77 \\
\hline a-Neoclovene & 1454 & 0.16 & \\
\hline$\beta$-Farnesene & 1458 & 0.80 & 1.75 \\
\hline Germacrene D & 1484 & 2.02 & 1.21 \\
\hline$\beta$-Ionone & 1485 & 0.51 & 0.47 \\
\hline Undecanoic acid & 1490 & 0.61 & 0.63 \\
\hline 2-Tridecanone & 1495 & 0.04 & \\
\hline Pentadecane & 1500 & 1.08 & \\
\hline Calamenene & 1523 & 0.43 & 0.43 \\
\hline a-Muurolene & 1524 & 3.85 & 2.72 \\
\hline (1-Butylhexyl)-benzene & 1526 & 0.15 & \\
\hline
\end{tabular}

RI; Kovats retention index

a As identified by GCxGC-TOF/MS software; names according to NIST mass spectral library, and by comparing their Kovats retention indices;

$\mathbf{b}$ Kovats retention indices of each component was collected from the literature for column Rxi 5ms; ${ }^{\mathbf{c}}$ Percentage of each component is calculated as peak area of analyze divided by peak area of total ion chromatogram times 100 (In the case of multiple identification, the areas of the peaks that belong to one analyze were combined to find the total area for this particular analyze); $\mathbf{d}$ Not detected

\section{Assessment of chromosomal damage, nuclear division} index and proliferative index

The results of micronucleus assay and SCE frequencies in human lymphocyte cells treated with DMSO as solvent control, EMS as positive control and HOE doses at 250, 500 and $750 \mu \mathrm{g} / \mathrm{ml}$ are shown in Table 2. These three doses were selected after a preliminary study performed within the range of $50-1750 \mu \mathrm{g} / \mathrm{ml}$ to determine the concentrations that would induce genotoxic activity and would not decrease the mitotic index (data not shown). An elevation in the MN frequencies was observed in the cells treated with 250,500 and $750 \mu \mathrm{g} / \mathrm{ml}$ concentrations of $\mathrm{HOE}$ compared to solvent control, however this increase was not significant at 250 and $500 \mu \mathrm{g} / \mathrm{ml}$ concentrations. A significant increase in the $\mathrm{MN}$ frequency was only observed at $750 \mu \mathrm{g} / \mathrm{ml} \mathrm{HOE}$. A significant increase in SCE ratio was detected when human lymphocytes were treated at a dose of 500 and $750 \mu \mathrm{g} / \mathrm{ml}(p<0.05, p<0.005$ respectively). NDI and PRI remained the same at selected doses of $\mathrm{HOE}$, which suggests that the extract does not act on the mechanisms pertaining to proliferation of the cells.

\section{Comet assay}

The outcomes of comet assay were expressed as the changes in the comet tail length, Olive tail moment, percentage of DNA in tail and head, DNA damage index (DDI) and percentage of damaged cells (Table 3 ). The results demonstrate that comet tail length, Olive tail moment, percentage of DNA in tail, DDI and percentage of damaged cells increased significantly at all concentrations compared to solvent control $(p<0.005$ and $p<0.0001$ ). EMS employed as positive control generated a more severe DNA damaging activity.

\section{Anti-growth effects of $\mathrm{HOE}$}

The anti-growth effect of the HOE (3.13-100 $\mu \mathrm{g} / \mathrm{ml})$ against MCF-7 and MDA-MB-231 cell lines was analyzed by the ATP viability assay after a $72 \mathrm{~h}$ treatment (Fig. 1). HOE significantly inhibited the growth of the MCF-7 and MDA-MB-231 cells in a dose-dependent manner $(p<0.05)$. $\mathrm{IC}_{50}$ and $90 \%$ inhibitory concentration $\left(\mathrm{IC}_{90}\right.$ ) were calculated as 26.3 and $91.2 \mu \mathrm{g} / \mathrm{ml}$ for MCF-7 and 39.0 and $92.9 \mu \mathrm{g} / \mathrm{ml}$ for MDA-MB-231, respectively. The sensitivity of both cell lines to anti-growth effects of $\mathrm{HOE}$ was similar even though the $\mathrm{IC}_{50}$ value for $\mathrm{MCF}-7$ cell line was slightly lower than that of MDA-MB-231.

\section{Type of cell death induced by HOE}

The mode of cell death triggered by HOE treatment was determined by fluorescence microscopy based on nuclear morphology and cell membrane integrity in breast cancer cells. We revealed that $\mathrm{HOE}$ treatment at $100 \mu \mathrm{g} / \mathrm{ml}$ concentration for $72 \mathrm{~h}$ resulted in nuclear shrinkage (pyknosis) in MCF-7 cells as illustrated in upper panel of Fig. 2. Likewise, nuclear shrinkage was noticed in some of the MDA-MB-231 cells as well. Pyknosis is a characteristic of apoptosis and pyknotic nuclei stained with Hoechst 33342 were indicated by white arrows in Fig. 2. However, these cells were also stained with PI signifying that membrane integrity was lost at this time point. Calcein-AM stains only viable cells and only a minority of the cells were stained with Calcein-AM in HOE treated MCF-7 and MDAMB-231 cells. 
Table 2. Results of Micronuclei (MN) and Sister Chromatid Exchange (SCE) assays in cultured human lymphocytes treated with HOE, positive and negative controls (Mean \pm SE)

\begin{tabular}{lcccccc}
\hline Treatment & Dose $(\mu \mathrm{g} / \mathrm{ml})$ & $\mathrm{N}^{\mathrm{a}}$ & \%o MN & $\begin{array}{c}\text { Nuclear division } \\
\text { index }(\mathrm{NDI})^{\mathrm{b}}\end{array}$ & $\begin{array}{c}\text { SCE/Cell } \\
\text { b }\end{array}$ & $\begin{array}{c}\text { Proliferative }^{\mathrm{b}} \\
\text { index (PRI) }^{\mathrm{b}}\end{array}$ \\
\hline Solvent control & - & 4 & $24.50 \pm 3.12$ & $1.16 \pm 0.03$ & $7.85 \pm 1.21$ & $1.92 \pm 0.04$ \\
& 250 & 4 & $34.93 \pm 6.67$ & $1.17 \pm 0.03$ & $10.67 \pm 1.10$ & $1.96 \pm 0.13$ \\
HOE & 500 & 4 & $37.20 \pm 4.45$ & $1.17 \pm 0.03$ & $12.47 \pm 1.09^{*}$ & $1.76 \pm 0.06$ \\
& 750 & 4 & $42.35 \pm 6.47^{*}$ & $1.19 \pm 0.01$ & $15.28 \pm 0.82^{* *}$ & $1.71 \pm 0.05$ \\
Positive control $^{c}$ & 1,250 & 4 & $45.00 \pm 7.10$ & $1.15 \pm 0.01$ & $25.37 \pm 3.25$ & $1.82 \pm 0.09$ \\
\hline
\end{tabular}

HOE; Hypericum olympicum subsp. olympicum methanolic extract.

${ }^{a}$ Number of donors; ${ }^{b}$ Significance compared with solvent control (0.1\% DMSO); ${ }^{c}$ EMS was used as positive control.

${ }^{*} p<0.05 ;{ }^{* *} p<0.005$.

Table 3. Results of comet analysis in cultured human lymphocytes treated with HOE, positive and negative controls in which 50 cells per donor were scored (Mean \pm SE)

\begin{tabular}{|c|c|c|c|c|c|c|c|}
\hline Treatment & Dose $(\mu \mathrm{g} / \mathrm{ml})$ & $\begin{array}{c}\text { Tail } \\
\text { length }{ }^{\mathrm{a}}(\mu \mathrm{m})\end{array}$ & Tail \% DNA ${ }^{a}$ & $\begin{array}{l}\text { Olive tail } \\
\text { moment }^{\mathrm{a}}\end{array}$ & Head \% DNA ${ }^{a}$ & $\begin{array}{l}\text { DNA Damage } \\
\text { index (DDI) }\end{array}$ & $\begin{array}{l}\text { Percentage of } \\
\text { damaged cells }\end{array}$ \\
\hline Solvent control & - & $4.23 \pm 0.09$ & $3.96 \pm 0.15$ & $0.53 \pm 0.02$ & $96.04 \pm 0.15$ & $0.21 \pm 0.06$ & $0.00 \pm 0.00$ \\
\hline $\mathrm{HOE}$ & $\begin{array}{l}250 \\
500 \\
750\end{array}$ & $\begin{array}{l}15.74 \pm 1.63^{* * *} \\
21.41 \pm 2.12^{* * *} \\
24.00 \pm 2.17^{* * *}\end{array}$ & $\begin{array}{l}11.88 \pm 1.42^{* * *} \\
14.13 \pm 1.67^{* * *} \\
18.15 \pm 1.89^{* * *}\end{array}$ & $\begin{array}{c}4.09 \pm 0.77^{* *} \\
6.10 \pm 0.96^{* * *} \\
7.66 \pm 1.04^{* * *}\end{array}$ & $\begin{array}{l}88.12 \pm 1.42^{* * *} \\
85.87 \pm 1.67^{* * *} \\
81.85 \pm 1.89^{* * *}\end{array}$ & $\begin{array}{l}0.65 \pm 0.03^{* * *} \\
0.77 \pm 0.07^{* * *} \\
1.05 \pm 0.04^{* * *}\end{array}$ & $\begin{array}{l}0.17 \pm 0.01^{* * *} \\
0.21 \pm 0.01^{* * *} \\
0.29 \pm 0.02^{* * *}\end{array}$ \\
\hline Positive control ${ }^{\mathrm{b}}$ & 1,250 & $110.71 \pm 5.53$ & $96.72 \pm 4.84$ & $56.94 \pm 2.85$ & $3.28 \pm 0.16$ & $3.92 \pm 0.06$ & $1.00 \pm 0.01$ \\
\hline
\end{tabular}

HOE; Hypericum olympicum subsp. olympicum methanolic extract.

${ }^{a}$ Significance compared with solvent control at ${ }^{*} p<0.05 ;{ }^{* *} p<0.005 ;{ }^{* * *} p<0.0001$.

${ }^{b}$ EMS was used as positive control.

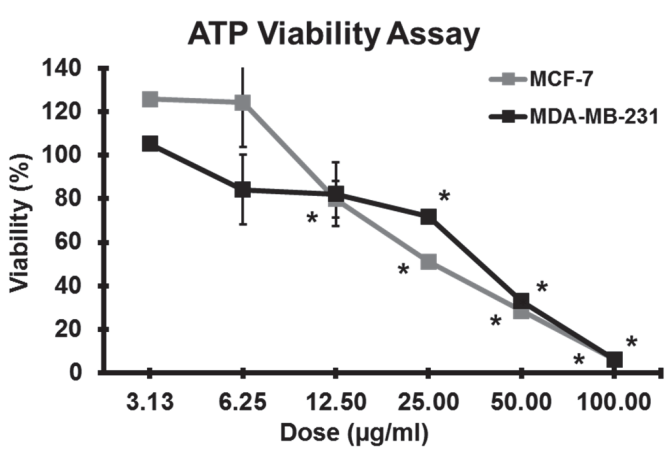

Fig. 1. Assessment of viability in MCF-7 and MDAMB-231 cell lines after $72 \mathrm{~h}$ treatment with varying doses of HOE by the ATP viability assay.

* Denotes significant differences compared with control $(p<0.05)$

To examine a possible apoptotic effect of HOE, we have measured the levels of M30, active caspase-3 and cleaved PARP. The level of M30 did not change following 25 and $50 \mu \mathrm{g} / \mathrm{ml} \mathrm{HOE}$ treatment in MCF-7 cells, but its level was increased at $100 \mu \mathrm{g} / \mathrm{ml}$ concentration (Fig. 3). M30 assay was not performed in MDA-MB-231 cell line as these cells have low cytokeratin 18 expression (Sommers et al., 1992). To find out the involvement of caspase-3 activation and PARP cleavage in cell death, we further performed ELISA assays after

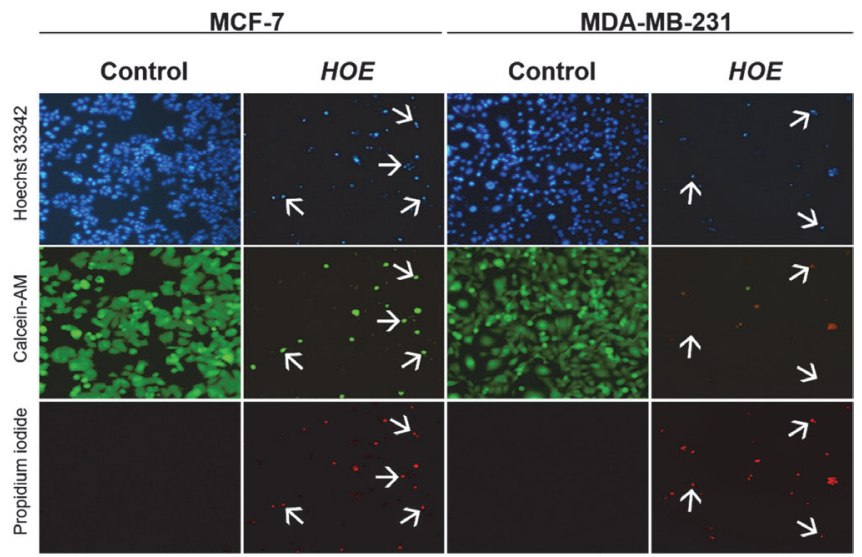

Fig. 2. Fluorescence imaging for determination of cell death mode in MCF-7 and MDA-MB-231 cells. Cells were treated with $100 \mu \mathrm{g} / \mathrm{ml}$ of the HOE for $72 \mathrm{~h}$. Upper panel shows Hoechst 33342 staining while middle and lower panels show calcein-AM and propidium iodide (PI) staining, respectively. Arrows indicate the cells with pyknotic/fragmented nuclei.

$100 \mu \mathrm{g} / \mathrm{ml}$ HOE treatment. We have observed no caspase-3 activation or PARP cleavage in MDA-MB-231 cells (Fig. 4A and B). PARP cleavage also did not occur in MCF-7 cells (Fig. 4A). Caspase- 3 activation was not assayed in MCF-7 cells as a result of a deletion in the gene that encodes procaspase 3 (Jänicke et al., 1998). A significant increase was observed in active caspase-3 and cleaved PARP levels after treating with paclitaxel $(3.12 \mu \mathrm{M})$ which was selected as positive control. 


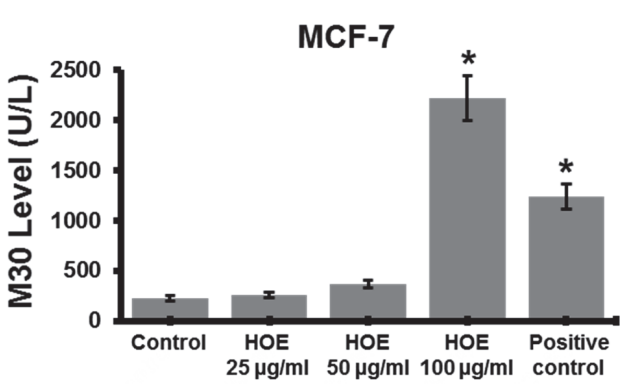

Fig. 3. The M30 levels (U/L) in MCF-7 breast cancer cells after treatment with HOE for $72 \mathrm{~h}$. Paclitaxel $(3.12 \mu \mathrm{M})$ was used as positive control for M30 increase. ${ }^{*}$ Denotes significant differences compared with control $(p<0.05)$

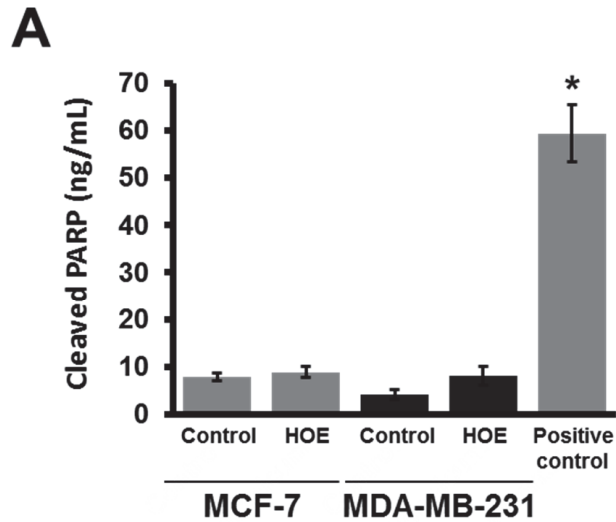

B

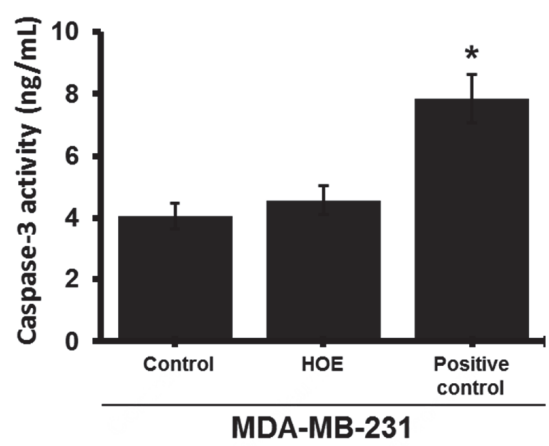

Fig. 4. Determination of cleaved PARP and active caspase-3 levels by ELISA. (A) Cleaved PARP levels in MCF-7 and MDA-MB-231 cell lines after $72 \mathrm{~h}$ treatment with $100 \mu \mathrm{g} / \mathrm{ml}$ concentration of HOE. Paclitaxel $(3.12 \mu \mathrm{M})$ treated MCF-7 cells were used as positive control. (B) Active caspase-3 levels in MDA-MB-231 cells treated with $100 \mu \mathrm{g} / \mathrm{ml} \mathrm{HOE}$ for 72 h. Paclitaxel (3.12 $\mu \mathrm{M})$ treated MDA-MB-231 cells were used as positive control. * Denotes significant differences compared with control $(p<0.05)$

\section{Discussion}

Medicinal plants are traditionally utilized worldwide against several diseases and eventually found their way into clinical practice due to their efficacy in cancer treatment (Cragg and Newman, 2005; Mann, 2002). Furthermore, genotoxicity analysis is also important to provide a risk assessment for human health (Bast et al., 2002). Hence, we evaluated both genotoxic and cytotoxic activities of HOE that still has use in traditional medicine regionally on human lymphocytes and breast cancer cell lines, respectively. We have shown that HOE had significant genotoxic activity at a higher dose range $(250-750 \mu \mathrm{g} / \mathrm{ml})$ based on SCE, MN and comet analyses in human lymphocytes in vitro.

No studies have been detected to focus on genotoxic activity of HOE, but there are several studies on other Hypericum species that still lacks agreement. For instance, Ramos et al. (2013) reported that $H$. perforatum presented a protective activity against oxidative damage in HT29 colon adenocarcinoma cell line; however, it was additionally revealed that the water extract of $H$. perforatum heightened the frequency of abnormal metaphases and chromosomal aberrations (Saadat, 2006). Water extract of a distinct species, $H$. heterophyllum was determined to elevate the MN levels in human lymphocytes. In general, these differences might arise from the interspecies differences, extraction methods or dose selection (Ocal and Eroğlu, 2012). Interestingly, some studies revealed that $H$. perforatum is not the most biologically active species in contrast to being the most widely known among the Hypericum genus (Stojanovic et al., 2013). Thus, it would be plausible to detect different levels of genotoxic/antigenotoxic activity in different species such as $H$. olympicum subsp. olympicum.

Our results demonstrated that $\mathrm{HOE}$ exhibited a similarly strong growth inhibitory effect on MCF-7 and MDA-MB-231 cell lines at relatively lower doses. Crude extracts of different species from Hypericum genus vary greatly in cytotoxic activity towards different cell lines. In our previous study, we have shown that $H$. adenotrichum methanol extract has superior cytotoxic activity against MCF-7 and MDA-MB-231 cell lines with $\mathrm{IC}_{50}$ values of 10.9 and $3.1 \mu \mathrm{g} / \mathrm{ml}$, respectively (Sarimahmut et al., 2016). On the other hand, there are findings in which other Hypericum species have demonstrated weaker cytotoxic activity. For instance, $H$. androsaemum water extract exhibited anti-growth effects against HCT15 and CO115 colorectal carcinoma cells at relatively higher concentrations (IC 50 values around 65 and $85 \mu \mathrm{g} / \mathrm{ml}$ ) (Xavier et al., 2012). In addition, Sarrou et al. (2018) found out that methanol extract of $H$. perforatum displayed a cytotoxic behavior at $100 \mu \mathrm{g} / \mathrm{ml}$ concentration in Caco-2 intestinal cancer cell line. Also, according to the criteria established by the U.S. National Cancer Institute on cytotoxicity of crude extracts, the $\mathrm{IC}_{50}$ values of HOE lie close to the cut-off value $(30 \mu \mathrm{g} / \mathrm{ml})$ between an "active" and "moderately active" compound (Suffness and Pezzuto, 1990). In the light of these data, HOE might be considered as "active". Notably, we have demonstrated that it requires a much higher concentration of HOE to exert genotoxicity in human lymphocytes than the doses which result in cell death in breast cancer cells. This leads to an advantageous situation if this species is considered for medicinal uses.

Our research group previously has shown that HOE exerts cytotoxic and apoptotic effects against lung cancer cells (Aztopal et al., 2016). It was also clearly observed in the current study that presence of pyknotic nuclei suggests apoptotic cell death in MCF-7 and MDA-MB-231 cells after a treatment of $100 \mu \mathrm{g} / \mathrm{ml}$ concentration in accordance with the findings of the anti-growth assay. In addition, the cells with pyknotic nuclei being positive for PI indicates that the cells undergo late stage apoptotic cell death (Hammill et al., 1999). Further verification of apoptosis was made through the increase in M30 levels in MCF-7 cells. In addition, caspase 3 activation and degradation of PARP were examined in order to better understand apoptosis-inducing effect of HOE (Soldani and Scovassi, 2002). Analyses in MDA-MB-231 cells suggest that the resulting cell death might be independent from caspase-3 activation, 
but additional analyses are needed. Absence of PARP cleavage which is commonly catalyzed by the effector caspases during apoptotic cell death implies caspase-3 independent cell death (Soldani and Scovassi, 2002).

HOE demonstrated its cytotoxic and genotoxic activities owing to a diverse chemical content. The methanol extract of the stamens from $H$. olympicum has hypericin and pseudohypericin components in approximately equal quantities (Kitanov, 2001). It was previously demonstrated that methanolic extract of $H$. olympicum subsp. olympicum to possess a rich flavonoid content such as rhamnetin, isorhamnetin and apigenin (Saddiqe et al., 2011). Recently, Llorent-Martinez et al. (2018) have identified 3-O-Caffeoylquinic acid as the most abundant phenolic acid and myricetin-O-deoxyhexoside as the dominant compound among flavonols in methanolic extract of H. olympicum in their study. There are a few reports in literature on the volatile compounds of HOE. Gudžić et al. (2001) identified 49 compounds and Pavlović et al. (2006) found 41 compounds including alkanes, monoterpenes, sesquiterpenes and oxygenated compounds. Moreover, Stojanovic et al. (2003) has determined 14 alkanes and 11 fatty acids in H. olympicum. It is apparent that DTD is superior in identifying a higher number of volatile compounds from $H$. olympicum subsp. olympicum. The major components of the flower and trunk were eicosane, heptacosane, 2-propen-1-ol, hexahydrofarnesyl acetone and a-muurolene. A number of furans, furanones and pyrazine compounds were also detected. These molecules were not original volatiles from $H$. olympicum subsp. olympicum which in fact were formed during thermal desorption unit heating process.

Some of the pharmacologically active constituents of H. olympicum L. spp. auriculatum were identified in a phytochemical profiling study and amentoflavone was detected as one of the active constituents while hypericin and hyperforin were not (Crockett et al., 2005). Another study that documents antioxidant potential and total phenolic and flavonoid content of $H$. olympicum and four other Hypericum species demonstrated that all plant extracts had a prominent antioxidant activity, but $H$. olympicum comprised the highest total flavonoid content compared to other four Hypericum species (Božin et al., 2013). Also, isolated acylphloroglucinols from H. olympicum L. cf. uniflorum were investigated by Shiu et al. (2011) for antibacterial activity and one of these compounds were found to have a strong antibacterial action.

\section{Conclusions}

In conclusion, a broad spectrum of polar and non-polar organic volatile compounds was analyzed from flower and trunk of $H$. olympicum subsp. olympicum using DTD coupled with GCxGC-TOF/MS. The methanolic extract of $H$. olympicum subsp. olympicum induced cell death in a dose-dependent manner against breast cancer cell lines and exhibited genotoxic activity at relatively higher doses in human lymphocytes. The cytotoxic activity of HOE determined in this study also points out the importance of dose selection if the plant extract is intended to be used as a remedy in traditional medicine.

\section{Conflict of interests}

The authors report no conflict of interests.

\section{Acknowledgements}

Funding Source: This work was supported by the Research Fund of Bursa Uludag University under Grants BUAP(F)-2014/3 and OUAP(T)-2015/19. The authors would like to thank Prof. Gur- can Guleryuz for his support in collection and identification of the plant and Ahmet Sari Mahmout for English editing and proofreading of the manuscript.

\section{References}

Ari F, Ulukaya E, Oran S, Celikler S, Ozturk S, Ozel MZ (2015). Promising anticancer activity of a lichen, Parmelia sulcata Taylor against breast cancer cell lines and genotoxic effect on human lymphocytes. Cytotechnology 67(3): 531-543. DOI: 10.1007/ s10616-014-9713-4.

Aztopal N, Erkisa M, Celikler S, Ulukaya E, Ari F (2016). Antigrowth and apoptosis inducing effects of Hypericum olympicum L. and Hypericum adenotrichum Spach. on lung cancer cells in vitro: Involvement of DNA damage. J Food Biochem 40(4): 559-566. DOI: $10.1111 /$ jbc.12248.

Barnes J, Anderson LA, Phillipson JD (2001). St John's wort (Hypericum perforatum L.): a review of its chemistry, pharmacology and clinical properties. J Pharm Pharmacol 53(5): 583-600. DOI: 10.1211/0022357011775910.

Bast A, Chandler RF, Choy PC, Delmulle LM, Gruenwald J, Halkes SBA, et al. (2002). Botanical health products, positioning and requirements for effective and safe use. Environ Toxicol Pharmacol 12(4): 195-211. DOI: 10.1016/S1382-6689(02)00035-2.

Baytop T (1984). Therapy with medicinal plants in Turkey. Istanbul, Istanbul University Press.

Bender O, Llorent-Martínez EJ, Zengin G, Mollica A, Ceylan R, Molina-García L, et al. (2018). Integration of in vitro and in silico perspectives to explain chemical characterization, biological potential and anticancer effects of Hypericum salsugineum: A pharmacologically active source for functional drug formulations. Plos One 13(6): e0197815. DOI: 10.1371/journal. pone.0197815.

Bingol U, Cosge B, Gurbuz B (2011). Hypericum species in flora of Turkey. Med Aromat Plant Sci Biotechnol 5: 86-90.

Božin B, Kladar N, Grujić N, Anačkov G, Samojlik I, Gavarić N, Čonić BS (2013). Impact of origin and biological source on chemical composition, anticholinesterase and antioxidant properties of some St. John's wort species (Hypericum spp., Hypericaceae) from the Central Balkans. Molecules 18(10): 11733-11750. DOI: 10.3390/molecules181011733.

Briskin, DP (2000). Medicinal Plants and Phytomedicines. Linking Plant Biochemistry and Physiology to Human Health. Plant Physiol 124(2): 507-514. DOI: 10.1104/pp.124.2.507.

Carrano AV, Natarajan AT (1988). Considerations for population monitoring using cytogenetic techniques. Mutat Res-Genet Tox 204(3): 379-406. DOI: 10.1016/0165-1218(88)90036-5.

Cragg GM, Newman DJ (2005). Plants as a source of anti-cancer agents. J Ethnopharmacol 100: 72-79. DOI: 10.1016/j. jep.2005.05.011.

Crockett SL, Schaneberg B, Khan IA (2005). Phytochemical profiling of new and old world Hypericum (St. John's Wort) species. Phytochem Analysis 16(6): 479-485. DOI: 10.1002/pca.875.

Davis PH, Mill RR, Tan K (1988). Flora of Turkey and the East Aegean Islands (Supplement), 10th ed. Edinburgh, Edinburgh University Press.

Fenech M (2000). The in vitro micronucleus technique. Mutat ResFund Mol M 455(1): 81-95. DOI: 10.1016/S0027-5107(00)000658.

Gudžić B, Dordević S, Palić R, Stojanović G (2001). Essential oils of Hypericum olympicum L. and Hypericum perforatum L. Flavour Fragr J 16(3): 201-203. DOI: 10.1002/ff.978.

Guner A, Ozhatay N, Ekim T, Başer KHC (2000). Flora of Turkey and the East Aegean Islands (Suppl. 2), 11th ed. Edinburgh, Edinburgh University Press.

Hammill AK, Uhr JW, Scheuermann R (1999). Annexin V staining due to loss of membrane asymmetry can be reversible and precede commitment to apoptotic death. Exp Cell Res 251(1): 16-21. DOI: 10.1006/excr.1999.4581.

Jänicke RU, Sprengart ML, Wati MR, Porter AG (1998). Caspase-3 is required for DNA fragmentation and morphological changes 
associated with apoptosis. J Biol Chem 273(16): 9357-9360. DOI: $10.1074 / j b c .273 .16 .9357$.

Kasımoğulları SÇ, Oran S, Ari F, Ulukaya E, Aztopal N, Sarimahmut M, Öztürk Ş (2014). Genotoxic, cytotoxic, and apoptotic effects of crude extract of Usnea filipendula Stirt. in vitro. Turk J Biol 38(6): 940-947. DOI: 10.3906/biy-1405-23.

Keskin C, Aktepe N, Yükselten Y, Sunguroglu A, Boğa M (2017). In-vitro Antioxidant, Cytotoxic, Cholinesterase Inhibitory Activities and Anti-Genotoxic Effects of Hypericum retusum Aucher Flowers, Fruits and Seeds Methanol Extracts in Human Mononuclear Leukocytes. Iran J Pharm Res 16(1): 210-220.

Kitanov GM (2001). Hypericin and pseudohypericin in some Hypericum species. Biochem Syst Ecol 29(2): 171-178. DOI: 10.1016/S0305-1978(00)00032-6.

Lamberti L, Ponzetto PB, Ardito G (1983). Cell kinetics and sisterchromatid-exchange frequency in human lymphocytes. Mutat Res Lett 120(2-3): 193-199. DOI: 10.1016/0165-7992(83)90163-X.

Llorent-Martinez EJ, Zengin G, Lobine D, Molina-Garcia L, Mollica A, Mahomoodally MF (2018). Phytochemical characterization, in vitro and in silico approaches for three Hypericum species. New J Chem 42: 5204า-5214. DOI: 10.1039/C8NJ00347E.

Mann J (2002). Natural products in cancer chemotherapy: past, present and future. Nat Rev Cancer 2(2): 143-148. DOI: 10.1038/ nrc723.

Mirmalek SA, Azizi MA, Jangholi E, Yadollah-Damavandi S, Javidi MA, Parsa Y, et al. (2015). Cytotoxic and apoptogenic effect of hypericin, the bioactive component of Hypericum perforatum on the MCF-7 human breast cancer cell line. Cancer Cell Int 16: 1-9. DOI: 10.1186/s12935-016-0279-4.

Newman DJ, Cragg GM (2016). Natural Products as Sources of New Drugs from 1981 to 2014. J Nat Prod 79: 629-661. DOI: 10.1021/ acs.jnatprod.5b01055.

Ocal A, Eroğlu HE (2012). Genotoxic Effects of Hypericum heterophyllum Vent. in Human Lymphocytes Cultures. Adv Lif Sci 2(3): 65-67. DOI: 10.5923/j.als.20120203.04.

Özel MZ, Göğüş F, Hamilton JF, Lewis AC (2004). The essential oil of Pistacia vera L. at various temperatures of direct thermal desorption using comprehensive gas chromatography coupled with time-of-flight mass spectrometry. Chromatographia 60(1-2): 79-83. DOI: 10.1365/s10337-004-0332-7.

Özel MZ, Göğüş F, Lewis AC (2006). Determination of Teucrium chamaedrys volatiles by using direct thermal desorptioncomprehensive two-dimensional gas chromatography-time-offlight mass spectrometry. J Chromatogr A 1114(1): 164-169. DOI: 10.1016/j.chroma.2006.02.036.

Ozkan EE, Ozsoy N, Ozden TY, Ozhan G, Mat A (2018). Evaluation of Chemical Composition and In-vitro Biological Activities of Three Endemic Hypericum Species from Anatolia (H. thymbrifolium, H. spectabile and H. pseudolaeve). Iran J Pharm Res 17(3): 1036-1046.

Pavlović M, Tzakou O, Petrakis PV, Couladis M (2006). The essential oil of Hypericum perforatum L., Hypericum tetrapterum Fries and Hypericum olympicum L. growing in Greece. Flavour Frag J 21(1): 84-87. DOI: $10.1002 / \mathrm{ff} .1521$

Perry P, Wolff S (1974). New Giemsa method for the differential staining of sister chromatids. Nature 251: 156-158. DOI: $10.1038 / 251156 \mathrm{a} 0$.

Ramos AA, Marques F, Fernandes-Ferreira M, Pereira-Wilson C (2013). Water extracts of tree Hypericum sps. protect DNA from oxidative and alkylating damage and enhance DNA repair in colon cells. Food Chem Toxicol 51: 80-86. DOI: 10.1016/j. fct.2012.09.014.

Saadat M (2006). Effects of Hypericum perforatum L. and Matricaria chamomilla L. extracts on the human chromosomes. J Pharmacol Toxicol 1(3): 289-292. DOI: 10.3923/jpt.2006.289.292.

Saddiqe Z, Naeem I, Maimoona A, Sautreau A, Hellio C (2011). Assay of flavonoid aglycones with HPLC in four species of genus Hypericum. J Med Plants Res 5(9): 1526-1530.
Sarimahmut M, Balikci N, Celikler S, Ari F, Ulukaya E, Guleryuz G, Ozel MZ (2016). Evaluation of genotoxic and apoptotic potential of Hypericum adenotrichum Spach. in vitro. Regul Toxicol Pharm 74: 137-146. DOI: 10.1016/j.yrtph.2015.11.010.

Sarrou E, Giassafaki LP, Masuero D, Perenzoni D, Vizirianakis IS, Irakli M, et al. (2018). Metabolomics assisted fingerprint of Hypericum perforatum chemotypes and assessment of their cytotoxic activity. Food Chem Toxicol 114: 325-333. DOI: 10.1016/j.fct.2018.02.057.

Shiu WK, Rahman MM, Curry J, Stapleton P, Zloh M, Malkinson JP, Gibbons S (2011). Antibacterial acylphloroglucinols from Hypericum olympicum. J Nat Prod 75(3): 336-343. DOI: 10.1021/ np2003319.

Singh NP, McCoy MT, Tice RR, Schneider EL (1988). A simple technique for quantitation of low levels of DNA damage in individual cells. Exp Cell Res 175(1): 184-191. DOI: 10.1016/0014-4827(88)90265-0.

Soldani C, Scovassi AI (2002). Poly (ADP-ribose) polymerase-1 cleavage during apoptosis: an update. Apoptosis 7(4): 321-328. DOI: 10.1023/A:1016119328968.

Sommers CL, Heckford SE, Skerker JM, Worland P, Torri JA, Thompson EW, et al. (1992). Loss of epithelial markers and acquisition of vimentin expression in adriamycin-and vinblastineresistant human breast cancer cell lines. Cancer Res 52(19): 5190-5197.

Sousa D, Xavier C, Lima C, Pereira-Wilson C, Fernandes-Ferreira M (2015). Cytotoxic activity of water extract fractions of Hypericum androsaemum L. on colorectal cancer cells. Planta Med 81(16): PW_78. DOI: 10.1055/s-0035-1565702.

Stojanovic G, Dordevic A, Smelcerovic A (2013). Do other Hypericum species have medical potential as St. John's wort (Hypericum perforatum). Curr Med Chem 20(18): 2273-2295. DOI: 10.2174/0929867311320180001.

Stojanovic G, Palic R, Tarr CH, Reddy CM, Marinkovic O (2003). n-Alkanes and fatty acids of Hypericum perforatum, Hypericum maculatum and Hypericum olympicum. Biochem Syst Ecol 2(31): 223-226. DOI: 10.1016/S0305-1978(02)00076-5.

Suffness M, Pezzuto JM (1990). Assays related to cancer drug discovery. In: Hostettmann K (Ed.). Methods in plant biochemistry: Assays for bioactivity, vol. 6. London: Academic Press.

Tian J, Zhang F, Cheng J, Guo S, Liu P, Wang H (2014). Antidepressant-like activity of adhyperforin, a novel constituent of Hypericum perforatum L. Sci Rep 4: 5632. DOI: 10.1038/ srep05632.

Tuzlac1 E, Aymaz PE (2001). Turkish folk medicinal plants, part IV: Gönen (Balıkesir). Fitoterapia 72(4): 323-343. DOI: 10.1016/ S0367-326X(00)00277-X.

Ulukaya E, Ozdikicioglu F, Oral AY, Demirci M (2008). The MTT assay yields a relatively lower result of growth inhibition than the ATP assay depending on the chemotherapeutic drugs tested. Toxicol In Vitro 22(1): 232-239. DOI: 10.1016/j.tiv.2007.08.006.

World Health Organization (1999). WHO monographs on selected medicinal plants, vol. 1. Geneva, World Health Organization.

Xavier CP, Lima CF, Fernandes-Ferreira M, Pereira-Wilson C (2012). Hypericum androsaemum water extract inhibits proliferation in human colorectal cancer cells through effects on MAP kinases and PI3K/Akt pathway. Food Funct 3(8): 844-852. DOI: 10.1039/ c2fo10226a.

Zorzetto C, Sánchez-Mateo CC, Rabanal RM, Lupidi G, Petrelli D, Vitali LA, et al. (2015). Phytochemical analysis and in vitro biological activity of three Hypericum species from the Canary Islands (Hypericum reflexum, Hypericum canariense and Hypericum grandifolium). Fitoterapia 100: 95-109. DOI: 10.1016/j. fitote.2014.11.013. 